\title{
Opposing Views on the Urgency for Healthcare Changes in the Netherlands: A Temporal Narrative Struggle
}

\author{
Martijn van Ooijen, Antonie van Nistelrooij, Marcel Veenswijk \\ VU University Amsterdam, Amsterdam, The Netherlands \\ Email: martijnvanooijen@gmail.com
}

How to cite this paper: van Ooijen, M., van Nistelrooij, A. and Veenswijk, M. (2018) Opposing Views on the Urgency for Healthcare Changes in the Netherlands: A Temporal Narrative Struggle. Journal of Service Science and Management, 11, 343-359. https://doi.org/10.4236/jssm.2018.114024

Received: June 20, 2018

Accepted: July 28, 2018

Published: July 31, 2018

Copyright ( 92018 by authors and Scientific Research Publishing Inc. This work is licensed under the Creative Commons Attribution International License (CC BY 4.0).

http://creativecommons.org/licenses/by/4.0/

\begin{abstract}
This paper illuminates the way multiple narratives concerning urgency for change dynamically interact on different levels and influence change processes in healthcare organizations. It explores the processes of sensemaking and opposing urgency narratives during a period of implementation for new legislation within the Dutch healthcare sector. Building on recent debates on process theory, narratives, and temporality, a new perspective on change urgency is presented, which shows how urgency is not unilaterally created from one position but is produced and reproduced by different editors in a narrative struggle. A temporal framework for change urgency was developed to study these narrative dynamics. Three urgency narratives contested the dominant narrative in the public discourse. The article shows how directors of healthcare organizations, dominated by these narratives, also hold narrative power. Managing change processes implies managing discourse.
\end{abstract}

\section{Keywords}

Change Urgency, Critical Discourse Analysis, Temporality, Narratives

\section{Introduction}

Worldwide, healthcare faces challenges due to rising expenditure as populations grow and age, technologies advance, and chronic conditions increase [1] [2] [3]. In the Netherlands, the costs of long-term health care are soaring rapidly [4], and structural measures are developed to remedy this. Little is known about the way such formal measures interact with processes of "sensemaking" and "sensegiving" on various stakeholder levels [3] [5]. This study explores the processes of sensemaking and sensegiving and analyzes the opposing urgency narratives in a 
period before the implementation of new legislation within the Dutch healthcare sector. In January 2015, the distribution and funding of long-term health care changed due to the implementation of a new law (the Wet Langdurige Zorg; WLZ), through which municipalities became responsible for social care while also receiving a reduced budget. The assumption was that organizing care locally would be more efficient. The responsibility for home nursing was delegated to health insurers. As a result of these measures, district nurses play a key role in integrating different aspects of health care [6]. Besides affordability, the argument for this move was that a decentralized system would be better able to meet the specific demands of increasingly self-determined and independent patients. The development and execution of these changes shape and continue to shape the lives of thousands of people who received health care or work in this sector. There are implications for patients, insurers, directors of healthcare organizations, and local governments. These changes are an example of New Public Management [2], and too often healthcare studies seem to simply support New Public Management developments, which, on the contrary, call for critical assessment via healthcare management papers [2] [7].

Through processes of sensemaking and discursive construction, situations become problems [8]. There is need for insight into the contexts and processes through which stakeholders cope with this ambiguity, as well as how their temporal interpretations contribute to change [9] [10]. Narratives are important sensemaking devices when facing uncertainty, and they help people to structure their thoughts and bring them into conversation with others [11] [12]. Although narrative analysis has received attention from scholars that study organizational change, there are still a lot of unexplored questions and blind spots for which narrative analysis is useful [10]. Following Vaara et al. [10], this study defines narratives as a "temporal, discursive construction that provides a means for individual, social, and organizational sensemaking and sensegiving." This study tries to fill the research gap by integrating temporality into change research [10]. Narratives are therefore analyzed in terms of how actors refer to the past, present, and future within the narrative [13]. To unveil narrative dynamics, as discussed by Haack et al. [14] for example, this study adopts a process perspective to unravel how narratives on change urgency emerge, interact with other narratives, develop, and terminate over time [15]. This study distinguishes between macro- and micro-level narratives [16]. People who receive health care or work in this sector are mostly spectators of the dialogues in the public debate and are oppressed by its narratives [17]. Therefore, this study pays attention to the way these macro-level narratives are interpreted by healthcare directors and considers their perspective on urgency for change [18] [19].

\section{Temporality and Power in Narratives}

Although several studies have contributed to insights on the role of temporality in the unfolding of change [20] [21], the way temporality structures narratives of 
change and the way sensegiving and storytelling influences change dynamics deserves attention from scholars [10]. This paper therefore pays attention to the way people use temporal elements like past, present, and future in their narratives to make sense of change. The temporal lens of this paper contributes to insights in the way different stakeholders construct urgency narratives and intensify change dynamics by taking different positions in and of time. Temporality is grounded in the works of Ricoeur [22] and Sartre [23] on Augustine's "threefold present of memory, expectation and attention" [13]. People recount past events from their memory, pay attention to the moment that passes from future into past, and from these experiences they develop expectations of the future. Gabriel [24] explains how temporal resources in narratives reflect dissatisfaction with the present situation. Often, the past or future is contrasted with the present situation, not to process past experiences (like mourning) but to cherish or dismiss experiences in the present. Whereas nostalgia contrasts the present situation with an idealized past, "postalgia" refers to the attempt to escape a problematic present by replacing it with an ideal future that appears reachable if only the gap between that ideal future and the present can be bridged. Ybema also describes a darker variant: "Anxious images of danger or decay, in which a future is sketched that is even darker than an already dark present" [25]. Such narratives have the function of making sense of experiences, not of presenting an accurate historical record or predictions of the future [13]. Time is thereby a human experience, and the stories we tell reflect our images of the self [24].

While narrative analysis focuses on sensemaking and sensegiving, critical discourse analysis focuses on the way power is exercised though language and how some narratives are privileged over others [26]. To comprehend the practices of power, Foucault's work on power, discipline, and discourse [27], helps to examine power dynamics. In this line of thought, Clegg describes frameworks of power as systems in which both micro and macro forces contribute to power flowing through circuits, shaping individuals, and forcing them to do or not do certain things [28]. In these frameworks of power, all actors both have power and are shaped by it. When an actor in the debate creates an urgency narrative, this does not assure the settlement of the narrative. A struggle between advocates and opponents producing counternarratives is to be expected [29]. Because power is used to accomplish the goals of the players in a field [30], urgency narratives reflect the underlying interests of their editor. Narratives in the discourse of the Dutch healthcare system entail technical rationality, which Habermas [31] would link to system. Besides the system narratives, the results of the current study show counternarratives emphasizing the underlife [26] of people dominated by the healthcare system. The leading question in this paper is: which narratives can be conceptualized and how did they discursively create change urgency in the debate over Dutch long-term health care? Besides expanding knowledge on temporality in narratives, this study aims to establish how narratives on the urgency for health care changes dynamically interact with 
other narratives in public and local debates.

\section{Methods}

This paper takes a "critical-action research approach" [2] to study both wider phenomena such as the discourse on the implementation of a new law, as well as the way healthcare managers deal with these developments in their everyday practice. Critical discourse analysis is adopted to study opposing logics and the dynamics of the narratives in discourse. Phillips and Hardy [32] differentiated between concept (the logic), object (the person) and subject position (the position of the stakeholder in the field). This "discourse ternary" separates the meaning of, for instance, patient or manager, the idea of what and who. The authors of this study work with the idea that meaning changes over time as the public debate changes. To reveal how the narratives in debate interact, the study pays attention to narrative techniques. Carlsen [33] has summarized six narrative techniques used by stakeholders during the process of policy implementation to exert narrative power. Carlsen distinguishes between framing, omission, fitting facts, means-to-aims, glorifying, and scapegoating. To study the different positions in the debate, this paper focuses on the following topics:

1) The structure and interrelationships of urgency narratives;

2) Narrative characteristics, focusing on temporal elements and discursive logic;

3) The key producers and editors of these narratives; and

4) Narrative techniques in use.

Following Vaara and Tienari [34], text materials from newspapers and other media (e.g., talk shows, websites, etc.) that pay attention to the healthcare debate are investigated in this paper, in addition to formal stakeholder information. To determine the reactions to and interpretation of events by key stakeholders, we have systematically analyzed all these documents. Four main sources of information are studied to explore the different change narratives in the debate. The first source of information is the official documentation from the government, including material such as letters from the government to parliament, the Netherlands Bureau for Economic Policy Analysis, the Central Agency for Statistics, and governmental websites from 2012 to the end of 2014. The second source is made up of scanned articles from nine Dutch newspapers that concern the structural changes in the year 2014. The third source, dating from after November 4, 2014, includes articles that react to an incident involving two declared whistle-blowers. In a news article in the Algemeen Dagblad on November 4, 2014, the two whistle-blowers-one of whom is the father of the secretary of state-explain how their wives had received low-quality healthcare treatment in a retirement home. Remarkably, the term whistle-blower was used in this instance, although it is more commonly used to refer to an internal member of an organization leaking information. That same evening, the second whistle-blower engaged in a debate with the secretary of state on the daily talk show Pauw. On November 17, two parliamentarians debated the proposed structural changes. The fourth source consists of transcripts of these two broadcasts. Table 1 
Table 1. Chronology of key events (timeline analysis, page 1).

\begin{tabular}{|c|c|}
\hline Date/Year & Key Events \\
\hline \multicolumn{2}{|l|}{ Prior to 2014} \\
\hline $4 / 2013$ & $\begin{array}{l}\text { Letter of the minister and secretary of state to parliament to } \\
\text { announce the future of long-term health care and a new law } \\
\text { (the WLZ) in place for } 2015\end{array}$ \\
\hline \multicolumn{2}{|l|}{ In 2014} \\
\hline $4 / 2014$ & $\begin{array}{l}\text { Several interest groups of patients, employees, municipalities, and } \\
\text { healthcare facilities call for a postponement of the announced } \\
\text { changes }\end{array}$ \\
\hline $11 / 4 / 2014$ & $\begin{array}{l}\text { Two seniors sound the alarm in a newspaper about the failing of } \\
\text { healthcare services for their demented wives. One of them is the } \\
\text { father of the secretary of state }\end{array}$ \\
\hline $11 / 4 / 2014$ & $\begin{array}{l}\text { One of the seniors debates the secretary of state about on Pauw, a } \\
\text { daily talk show, about the present situation in healthcare facilities } \\
\text { and the announced changes in long-term healthcare }\end{array}$ \\
\hline $11 / 17 / 2014$ & $\begin{array}{l}\text { A parliamentarian of the ruling left-wing party goes on Pauw to } \\
\text { debate an opposition parliamentarian and argues that the } \\
\text { management in healthcare facilities is to blame for the poor health } \\
\text { care provided by such facilities }\end{array}$ \\
\hline $1 / 2015$ & Implementation of the new healthcare law WLZ \\
\hline
\end{tabular}

provides an overview of the main chronology of events. The research materials were closely read to interpret emergent meanings in the narrative logic [18]. A holistic content perspective supported the data structuring and coding process [35].

To further analyze the narratives, we investigated their development and issue attention in the nine newspapers. Because issue attention is crucial for changes in the public domain [36], we focus on the rise and fall of the different narratives based on their issue attention in the media in 2014. Because qualitative data improves the quality of narrative analysis [36], four directors of two healthcare organizations (for elderly and mental health care) were interviewed using a semi-structured interview format. The interviewees provided retrospective perspectives about the four macro narratives, the way these narratives contributed to stability or change in their organization [10], and their personal urgency narratives. For their personal narratives, Carlsen's narrative questions were adopted [33].

\section{Results}

\subsection{The "Brink of Disaster" Narrative}

Dutch governmental agencies such as the Ministry of Health, Welfare and Sports, were key producers of the "brink of disaster" narrative (disaster-narrative). The concept concerned the entire system of long-term health care. The subject position of the key producer was the affordability of the current healthcare system in the future and the need for structural change. According to this narrative, be- 
cause of the growing relative number of pensioners and higher life expectancy, the Dutch healthcare system was becoming too expensive. If no action as taken, health care would quickly become problematic: in other words, the Netherlands was on the brink of disaster. To solve the problem, key editors argued that structural changes in the healthcare sector were necessary. In the government messages, it was clear that there was going to be crisis if there was no response to the urgent situation. Consultancies such as McKinsey also emphasized the problem by explaining how, by doing nothing to cut costs, the Netherlands would end up using roughly one quarter of its GDP and one quarter of the working population to provide curative healthcare (cure) and long-term healthcare (care) [4].

The tone of this narrative was a little frightening; the whole country was on the brink of disaster, which called for a quick and strong response. In this narrative, the quality of health care was also problematized. In the Pauw broadcast, the secretary of state stressed the aggravation of the level of health care for which the nursery homes were not prepared [37]. From a temporality perspective, the projected future seemed to play an important role. This argumentation for change was framed as a future imperfect, requiring action. Through this narrative, the government announced the proposed changes. In this narrative, healthcare patients were considered autonomous, independent objects with a social network able to support them. The secretary of state explained how people want to live at home as long as possible and not be lonely. Often support from the patients' social network or (municipal) homecare would be required. He argued that if living at home were no longer possible, good nursing homes that pay attention to the individual and quality of life should be available [38].

It was important for key editors to stress the autonomy and independence of the patient because the new law was designed so that certain nursing tasks would not be part of the secured health care in the future. As a result, in this narrative the patients' social networks were considered strong and able to take over these tasks. Moreover, the current system had become a patch for loneliness. In this narrative, the idea was that the Netherlands should not go back to a time when social participation was dependent on charity. At the same time, a society in which loneliness was solved through financed and insured healthcare as unappealing idea in this narrative [38].

\subsection{The "Postpone It" Narrative}

Several stakeholders in the healthcare industry stressed their concern about the tempo of the proposed changes through press releases, petitions, and letters to the Parliament [34]. First, Abvakabo FNV, the largest Dutch public sector trade union, requested a postponement, arguing that municipalities were not ready to execute the necessary tasks on January 1, 2015 [39]. Second, NRC communicated that the social insurers' interest group Zorgverzekeraars Nederland sent a letter to Parliament, saying they were not ready for the implementation of the 
new law, because of the tempo, simultaneity, and extensiveness of the changes. According to this narrative, healthcare changes for vulnerable seniors, severely ill children, or people with protracted psychological problems demanded great thoughtfulness [40]. Third, Actiz, the industry association of healthcare organizations, agreed with the proposed changes, but claimed that the deadline of January 1 was too early. They explained how healthcare facilities had already closed because of the changes, while family members and healthcare organizations needed more time to adapt to the new situation. Their fear was that vulnerable seniors were the ones most likely to slip through the cracks [41]. Fourthly, Chairman Wilna Wind of the patient interest group NPCF argued that if care providers said they were not ready for the changes, a solid implementation of the WLZ would not be possible [41].

Lastly, three political parties-SP, CDA and Groen Links-in the Dutch parliament also wanted the government to postpone the structural changes. Their common argument was to allow more preparation time for the municipalities, but their individual arguments differed. For instance, Mona Keijzer of the CDA argued that the feedback from society hopefully would not fall on deaf ears [42]. Although several industry stakeholders endorsed this narrative, the secretary of state rejected the claim and argued that it was too late to back off at that point [43]; indeed postponing would enlarge the problems of the people concerned [42].

This narrative did not challenge the core elements of the disaster-narrative. The "postpone narrative" (postpone-narrative) focused particularly on the timing and tempo of the implementation of the changes. From a temporality perspective, it is remarkable that the "newly designed" future was portrayed as highly problematic. There were no objects in this narrative, although "vulnerable patients" were mentioned in general. It was important to stress the vulnerability of the patients, because to make this narrative powerful, it was necessary to dramatize the consequences for the people involved.

\subsection{The "Shit Hits the Fan Right Now" Narrative}

Key editors of the "shit hits the fan right now" counternarrative (shit-narrative) were two proclaimed whistle-blowers. They shared their story about how poorly their wives were treated in a Dutch nursing home in the newspaper Algemeen Dagblad on November 4, 2014. Several national newspapers and other media organizations picked up the story. The concept in this narrative was the situation in nursing homes. In the Algemeen Dagblad article, the secretary of state's father explained how his wife received poor supervision and support for her incontinence: "When she stands up, the urine is flowing down her ankles."

The father of the secretary of state went on to explain that often there was no staff around, especially on weekends. People called him the "servant" because he watched over the patients. Together they expressed their discontent in the paper by explaining that employees did not wait by the patient until the pills were 
swallowed, because the workers claimed they had no time. The father explained that he found pills in the ashtray or in the pockets of his wife's trousers, which he thought problematic because she has diabetes and high blood pressure. "Sometimes there is only one nurse who must service three rooms with six patients per room" [44].

During the broadcast of the talk show Pauw later that evening, the other whistle-blower-in conversation with the secretary of state-emphasized the problematic and inhumane situation in the nursing home where his wife lives. In this broadcast, the shit-narrative encountered the disaster-narrative. The whistle-blower argued that at that moment, the nursing home already had to work with insufficient personnel because of recent budget cuts. He wondered what would happen in 2015, when more budget cuts were planned. In this narrative, the concept of the proposed structural changes was referred to as budget cuts by both the whistle-blower and the opposition parliamentarian [37]. The key editor was the opposition parliamentarian who revised this narrative by explaining how the healthcare budget was functioning below its cost price and the parliamentarian blamed the government for the bad measures causing the inhumane situation in nursing homes [37]. In addition to key editors such as the parliamentarian and the whistle-blower, several newspapers and other media outlets like Twitter picked up this narrative.

From the temporality perspective, it is interesting to see how the key editors paid significant attention to the present to explicate their position on the urgency for change. Within the narrative, they used information about structural changes as part of an argument for how the situation would go from bad to worse. The objects are patients, who were portrayed as being dependent and needy. This strongly contradicted the disaster-narrative, in which patients were portrayed as independent, autonomous individuals. Like the postpone-narrative, it was important to dramatize the consequences for people with whom a listener would probably sympathize. One of the whistle-blowers died shortly before the broadcast of Pauw on November 17, and was called a hero and whistle-blower during the talk show.

\subsection{The "Scapegoating Management" Narrative}

Another parliamentarian and the secretary of state (both members of the same left-wing party) produced a new counternarrative to respond to the shit-narrative. In this counternarrative, the management of the nursing homes was made a scapegoat, to allow politicians to dodge the blame placed on the government by the shit-narrative. The parliamentarian argued that the story of the whistle-blowers was "unfortunately not a unique situation but an unpleasant reality" [37]. The subject position is that every year, health care for the elderly received extra funds. There were organizations that used it properly, and there were ones that did not. According to the governmental parliamentarian: "There are also organizations that use it for a big salary for the president, an expensive PR de- 
partment, management, cars, 'paper machine' bureaucracies" [37].

According to this parliamentarian, low overhead should be the norm: good examples existed, and the focus should be on these organizations. Shortly after November 4, the secretary of state also edited this narrative by taking extra measures and linking them to the development of a law for good management in health care: "Nursing homes where healthcare service is insufficient will receive enhanced surveillance of the inspection for healthcare. Management of organizations that repeatedly do not perform will be addressed. If there are no improvements, another organization should take over the management of the facilities" [37]. The key producers of this narrative did not reject the disaster-narrative, but dodged the shit-narrative by the "scapegoat management" counternarrative (scapegoat-narrative). The key editors of the disaster- and scapegoat-narrative overlapped.

\subsection{Textual Interrelationships among (Counter) Narratives}

To show how the disaster-narrative and its counternarratives are connected, we draw attention to the four core textual structures and how they relate to one another. The overview of Table 2 presents the narrative elements through which they are connected and, following Carlsen, the narrative techniques in use [33].

\subsection{Narrative Analysis}

To analyze how the four narratives developed and declined over time, we examine their issue attention in the nine studied newspapers and then inspect the narrative field and the characteristics of the four narratives. Because the item interviewing a whistle-blower and the secretary of state was published in the $\mathrm{Al}$ gemeen Dagblad, this newspaper was one of the main editors of this narrative.

When considering the appearance of all news items on the long-term healthcare situation in 2014, Figure 1 shows that there were two major attention spikes. The first concerned the deal about structural changes in long-term health care and the discussion about the implementation of the new law in January 2015 between ruling parties and the opposition. The second was the media attention to the whistle-blowers' news item. The first spike showed the peak of the postpone-narrative, which declined after news of the political deal. In the following months, this narrative was revisited-for instance in July-but no longer received significant attention in the newspapers. When the law was implemented on January 1, 2015, the concept of this narrative became irrelevant, as it was no longer possible to postpone implementation of the law. The figures illustrate the dynamic way the four narratives respond to each other and developed and declined over time.

Three of the four narratives peaked in November. The shit-narrative responded to the disaster-narrative and both received attention in the newspapers. Figure 2 shows how the scapegoat-narrative rose when the shit-narrative declined and illustrates the way the scapegoat narrative tried to overthrow the shit-narrative. 
Table 2. Textual interrelationships among narratives (narrative technique analysis, page 1-2).

\begin{tabular}{l} 
Narrative \\
\hline Disaster-narrative $\quad \begin{array}{l}\text { Framing: framing the current long-term health care in a financially problematic way; only a quick response can solve } \\
\text { the problem. } \\
\text { Fitting facts: using specific data to support the narrative (estimations of the future healthcare costs per family). }\end{array}$ \\
$\begin{array}{l}\text { Framing: framing the implementation of the WLZ in a problematic way for the organizations involved; only } \\
\text { postponing WLZ implementation will solve the situation. } \\
\text { Means-to-aims. while the problem in the disaster-narrative is affordability and the solution is a quick implementation, } \\
\text { in this narrative the focus is on the means, that is, the timing and pace, which is problematized. }\end{array}$ \\
Postpone-narrative \\
$\begin{array}{l}\text { Framing: framing both current long-term health care and the WLZ in a problematic way for the receiving party: the } \\
\text { patients. The WLZ is framed as an additional budget cut. } \\
\text { Scapegoating: the government is to blame for the inhumane situation and should stop economizing on health care. }\end{array}$ \\
$\begin{array}{l}\text { Framing: framing the current situation in health care facilities is caused by the management in these facilities. } \\
\text { Omission: to counter the shit-narrative, key elements of the shit-narrative, like the WLZ and budget cuts, are omitted; } \\
\text { the current inhumane situation is uncoupled from the healthcare reforms. } \\
\text { Scapegoating: the management at the facilities-not the government-is to blame for the inhumane situation and } \\
\text { should be removed. }\end{array}$ \\
Scapegoat-narrative
\end{tabular}

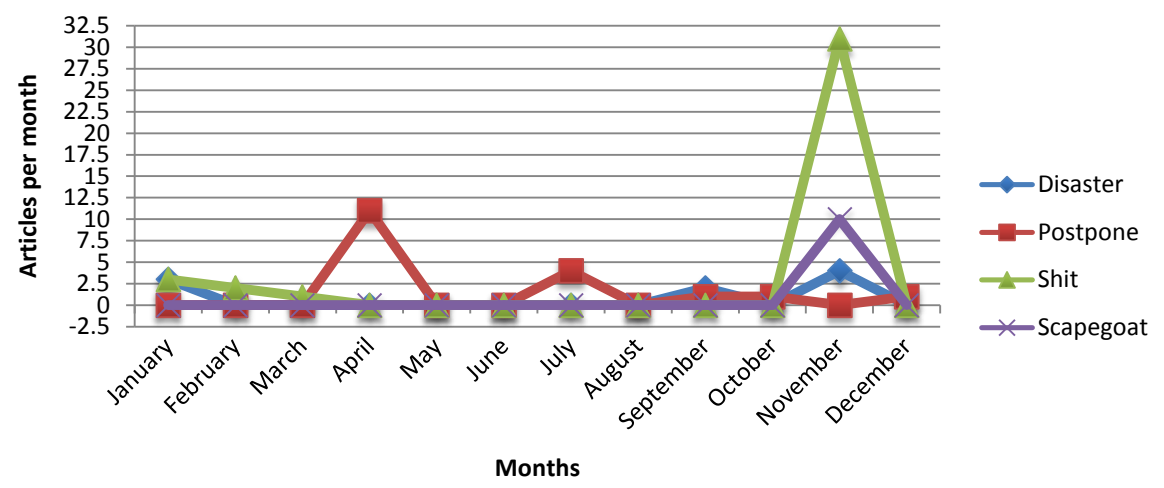

Figure 1. Issue attention, narrative per month (issue attention analysis, page 1).

The narrative analysis shows a polyphonic debate as the different narratives struggled for attention. Three narratives countered the initial disaster-narrative. The narrative struggle reveals how different editors highlighted different aspects of the changes, took different temporal positions, and adopted various narrative techniques. The disaster-narrative resembles Ybema's postalgia, a dark future contrasting with the problematic present, while the shit-narrative more closely resembles nostalgia. The scapegoat-narrative responded to the problematization of the present and dodged the shit-narrative by scapegoating the management of the nursing homes. Because the shit-narrative was potentially a hiccough for the implementation of the new law, the scapegoat-narrative seems to be designed to defeat the shit-narrative and clear the way for the new law to take effect in January 2015. Moreover, the interests of the editors in the narratives become visible, by which they become power devices. The narratives aimed to win the narrative struggle and shift the field of health care in a direction matching the interests of its stakeholders. For instance, the shit-narrative seems to secure the interests of patients receiving health care today. This narrative was followed by 


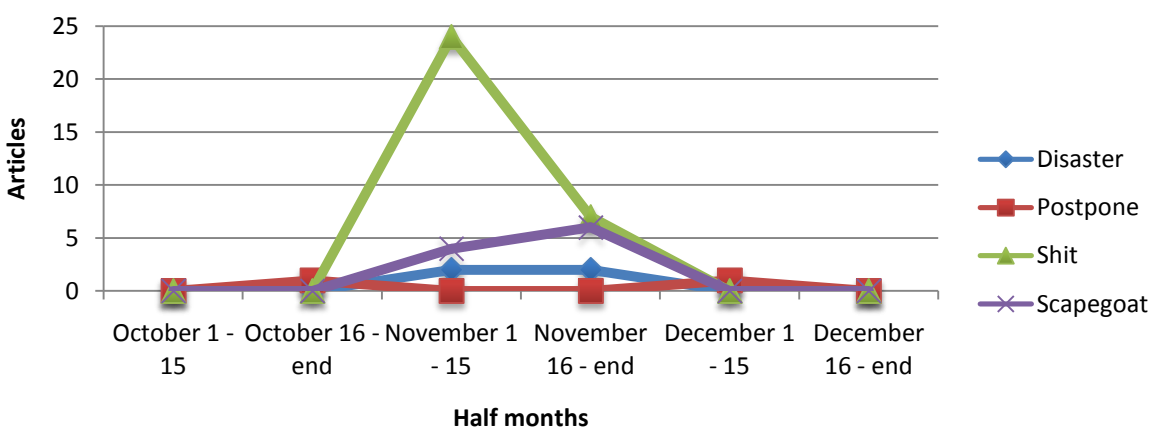

Figure 2. Issue attention: quarter 4 in detail (issue attention analysis, page 1).

the scapegoat-narrative, which had significant consequences for people that manage healthcare facilities. The following section allows four healthcare directors to comment on these narratives.

\subsection{Local Interpretations of Macro Level Narratives}

This section presents interpretations of these four narratives by healthcare directors. Four directors were interviewed in retrospect as to whether they recognized and perceived the four macro-level narratives. The focus was on whether they believed these narratives contributed to stability or change, as well as their own personal urgency narrative. All four directors recognized the four narratives as presented in Section 3 of this article; their reactions are summarized for each narrative.

Disaster-narrative. The four directors argue that the affordability of long-term health care was the strongest issue of the narrative. They feel this element of the narrative was eventually neglected by its main editor, the secretary of state. An absent but relevant element of the disaster-narrative was the connection between the aggravating level of health care and education and schooling. Although they all stress the autonomy of patients, they question the assumption that patients possess a strong social network. One director argues that the families of patients are also old and therefore not always capable of taking care of their relatives. All directors recognize this narrative as part of the management discourse, not of the employee discourse. They view this narrative as a change narrative, although they needed to reframe the narrative for their own change agenda.

Postpone-narrative. For the directors, the postpone-narrative contributed to stability. All directors recognize the magnitude of the changes, but they believe the call for postponement did not help overcome the challenges. One director explains how this narrative contributed to doubt among stakeholders, but also among colleagues working in the projects preparing for the implementation of the new law. The main editors of the narrative claimed to represent the workers within the sector, but these directors contest this. One manager suggests that this narrative was the product of power play by some very powerful healthcare directors within the industry organization Actiz.

Shit-narrative. All directors say the shit-narrative contributed to stability and 
contradicted the disaster-narrative: when you stress patient autonomy and reducing the amount of health care, incidents like those contained in the shit-narrative are a consequence that should not be problematized. Mismanagement of incontinence is part of the life of these patients, they say. Framing these situations as serious incidents contributed to more rules and regulations and less focus on learning and development. Two directors explain how they experienced their own variant of the shit-narrative. With the help of blogs and other media, similar staffing issues in their organization became "incidents" and ultimately led to the directors' departure. This narrative also made the sector less attractive to work in, while the changes require more and better educated employees. One director argues that employees in his organization felt misunderstood as a result of the way their work was portrayed in the media.

Scapegoat-narrative. Although the directors believe this narrative was very negative and contributed to stability, they all recognized that incidents where directors enrich themselves were a problem. However, this narrative supports the focus on preventing incidents like these from happening. They argue that focusing on control reduces the focus on the autonomy of patients: "Yes, back in the wheelchair Mrs. Jansen" (to prevent her from falling). One director explains how the shit-narrative and the scapegoat-narrative created and still creates a rat race for healthcare directors with winners and losers. Another director believed that in the focus on incidents and management a new type of director arises: the hero that comes to rescue.

The directors formulated their personal urgency narratives as shown in Table 3.

The personal urgency narratives of the directors are mostly postalgias in which the present is problematized and the horrific future is the subject of fear and anxiety.

\section{Discussion}

In this study, opposing urgency narratives concerning the implementation of new legislation within the Dutch healthcare sector are explored. The focus was on the dynamic interplay of urgency narratives in public and local discourses. The urgency narratives all took a different temporal viewpoint, which intensified the narrative dynamics. The announcement of change by the secretary of state via the disaster-narrative resulted in several counternarratives, but eventually shifted the field. The disaster-narrative had the function of facilitating the implementation of a new law in January 2015. Editors of the postpone- and shit-narrative narratives tried to influence the public discourse by producing alternative urgency narratives that highlighted additional aspects of the situation to win the battle and shift the field in the preferred direction or tempo. In this contest, the postpone- and shit-narratives "died in combat," while the scapegoat-narrative supported the disaster-narrative.

The Pauw broadcast showed how the system and real world narratives failed to connect. While these institutional changes resulted in significant consequences 
Table 3. Personal urgency narrative per director (transcripts 1-4, interview analysis).

\begin{tabular}{|c|c|}
\hline Director & Personal Urgency Narrative \\
\hline 1 & $\begin{array}{l}\text { The challenge is to make long-term health care more personal instead of one-size-fits-all. To do this, we need to allow } \\
\text { teams and employees to do their own decision-making and to improve human relations. Unfortunately, in my organization, } \\
\text { my successor is reversing my measures to stimulate learning and development. }\end{array}$ \\
\hline 2 & $\begin{array}{l}\text { Health care must change because of the problem of affordability. This requires that the whole system changes. The } \\
\text { challenge is to get all stakeholders to change. "It's all about working with checklists of who is good and who is not."People } \\
\text { in the sector that I know are worried about the labor market and the demand for high-level manpower. I am concerned } \\
\text { about whether the changes will succeed in the sector. }\end{array}$ \\
\hline 3 & $\begin{array}{l}\text { The challenge is to get the sector away from checklists and to start trusting each other again. This implies focusing on } \\
\text { quality care and outcomes instead of accountability. The way to do this is to start more experiments in rule-free } \\
\text { environments. We need all actors to contribute in all areas, including inspection, care agency, the politics, and management } \\
\text { of healthcare organizations. "For me it is a culture of distrust. And this is part of the Anglo-Saxon model of control and } \\
\text { supervision and if we don't stop it now, nothing is going to change." }\end{array}$ \\
\hline 4 & $\begin{array}{l}\text { The challenge is to create co-responsibility to deliver quality care with all parties in the field. The challenge for leaders is to } \\
\text { stand up in the rat race of the long-term healthcare to support this co-responsibility and change, which can be challenging, } \\
\text { especially in big organizations. }\end{array}$ \\
\hline
\end{tabular}

for stakeholders, the voice of the narrative objects was limited. These fixated positions in the debate worsened the struggle and were a potential thread for the disaster-narrative. Macro- and micro-level narratives also collide. On the microlevel, directors drew contrary conclusions about the situation in health care, while the macro-level narratives significantly shaped their working environment. The directors were especially critical of the secretary of state-the key producer of the disaster-narrative-for taking an inconsequent position on the shit- and scapegoat-narratives, thus contributing to a rat race of winners and losers. The directors feared an overstrained healthcare sector with a focus on control measures and an inadequate amount of high-quality manpower. Stories like the shit-narrative and scapegoat-narrative make the sector less attractive to future employees. Two of the directors connected their departure to the narratives in the public discourse. These micronarratives show how the working lives of the directors and their employees are shaped by the narratives in the public discourse. However, the directors also hold power in developing alternative logics in narratives that can "survive" the battlefield.

\subsection{Theoretical Implications}

By observing the processes of narrative development on several levels on a specific time frame, this study contributed to an in-depth view of the narrative dynamics in the Dutch healthcare sector. The result of this paper contributes to the debate on narratives and temporality, first by revealing how the temporal positions of the editors play a key role in the struggle of urgency narratives in public and local debates. Second, the results reveal how storytelling on different levels further feeds the dynamic struggle of this change process. This study shows that there are more temporal narrative strategies than nostalgia and postalgia. Since the results of this study point to a broader understanding of temporal interpreta- 
tions in narrative struggles than postalgia and nostalgia, further research could provide additional insight on the multiple manifestations of urgency narratives in change processes. In terms of power, the urgency narratives in this study contribute to the idea of frameworks of power [28] in which narratives on different levels have the function and potential to control or change the discourse.

\subsection{Practical Implications}

Managing change in complex change processes implies managing discourse. In the battlefields in which urgency narratives compete, only the strongest urgency narratives survive. Manages confronted with change should not focus only on dominant or highly visible urgency narratives, however; micro narratives also contribute to the framework of power and can in time shift an entire organization or field. Managers and policy makers confronted with change should be aware of and sensitive to different temporal interpretations of change urgency. First, a practical suggestion for managers in change processes is to invite input from various voices to discover these diverse temporal interpretations. Second, managing organizational change also requires narrative skills like reframing macro narratives for local change initiatives.

\subsection{Limitations and Future Directions}

A first limitation of this study is the limited number of stakeholders interviewed. Walgrave and Varone [36] argue that case study material and qualitative data improve the quality of narrative analysis. For this paper, a media analysis was adopted and four directors were interviewed, resulting in rich data. However, interviewing more stakeholders would probably result in additional insights. A second limitation is the generalizability of the interpretations of the data. Adopting the approach of this study in similar contexts could potentially contribute to knowledge on urgency narratives in change processes, sensemaking, sensegiving, and temporality.

The framework of change urgency and the method of issue attention provide a means to study the dynamic development and termination of urgency narratives. Further research could provide additional insight on the distinctive manifestations of urgency narratives. In a way, this study bridges approaches from process theorists [15], who stress studying the development of phenomena over time, and the narrative theorists [10], who stress studying how language creates realities and power relationships. This paper follows up on Granqvist and Gustafsson [9] and Vaara, Sonenshein, and Boje [10], which both stress studying temporality in narrative struggles. We invite more change scholars to follow this line of thinking.

\section{Conclusion}

This study explores processes of sensemaking and sensegiving and analyzes urgency narratives in a period before the implementation of new legislation within 
the Dutch healthcare sector. The leading question in this paper is: which urgency narratives can be conceptualized and how do they discursively create change urgency in the debate on Dutch long-term health care? A framework was developed to study narrative dynamics. After the announcement of change by the secretary of state via the disaster-narrative, three narratives followed: a postpone-narrative, shit-narrative, and scapegoat-narrative. Although the disaster-narrative was challenged, it eventually succeeded in shifting the field. The narrative struggle in the public debate among these narratives influenced local sensemaking processes. Directors of healthcare organizations are especially critical of the key producer of the disaster-narrative for taking an inconsequent position on the shit- and scapegoat-narratives and thereby contributing to a rat race of winners and losers that strain the healthcare sector with its focus on control measures and insufficient high-quality manpower. Stories like the shit-narrative and the scapegoat-narrative make the sector less attractive to future employees. This paper contributes to theoretical studies of temporality by showing how the temporal positions of narrative editors play a key role in intensifying narrative struggle. This paper also contributes to the idea that managers hold narrative power to develop strong urgency narratives themselves. Managing discourse is an implied necessity for managing change processes.

\section{Conflicts of Interest}

The authors declare no conflicts of interest regarding the publication of this paper.

\section{References}

[1] Nicholls, A. and Brayshaw, L. (2018) Global Outlook: Healthcare. The Economist Intelligence Unit 2014.

[2] Hassard, J., Hyde, P., Wolfram Cox, J., Granter, E. and McCann, L. (2017) Exploring Health Work: A Critical-Action Perspective. Journal of Health Organization and Management, 31, 567-580. https://doi.org/10.1108/JHOM-02-2017-0034

[3] Warwick-Giles, L. and Checkland, K. (2018) Integrated Care: Using "Sensemaking" to Understand How Organizations Are Working Together to Transform Local Health and Social Care Services. Journal of Health Organization and Management, 32, 85-100. https://doi.org/10.1108/JHOM-03-2017-0057

[4] Van Rooijen, M., Goedvolk, R. and Houwert, T. (2013) A Vision for the Dutch Health Care System in 2040: Towards a Sustainable, High-Quality Health Care System. In World Economic Forum, McKinsey \& Company, New York City.

[5] Gilbert, F., Denis, J.L., Lamothe, L., Beaulieu, M.D., D’amour, D. and Goudreau, J. (2015) Reforming Primary Healthcare: From Public Policy to Organizational Change. Journal of Health Organization and Management, 29, 92-110. https://doi.org/10.1108/JHOM-12-2012-0237

[6] Kroneman, M., Boerma, W., Van den Berg, M., Groenewegen, P., De Jong, J. and Van Ginneken, E. (2016) Netherlands: Health System Review. Health Systems in Transition, 18, 1-240.

[7] Kitchener, M. and Thomas, R. (2016) The Critical Health Care Management Do- 
main. The Oxford Handbook of Health Care Management, 117.

[8] Maitlis, S. and Christianson, M. (2014) Sensemaking in Organizations: Taking Stock and Moving Forward. The Academy of Management Annals, 8, 57-125. https://doi.org/10.5465/19416520.2014.873177

[9] Granqvist, N. and Gustafsson, R. (2016) Temporal Institutional Work. Academy of Management Journal, 59, 1009-1035. https://doi.org/10.5465/amj.2013.0416

[10] Vaara, E., Sonenshein, S. and Boje, D. (2016) Narratives as Sources of Stability and Change in Organizations: Approaches and Directions for Future Research. The Academy of Management Annals, 10, 495-560. https://doi.org/10.5465/19416520.2016.1120963

[11] Berendse, M., Duijnhoven, H. and Veenswijk, M. (2006) Editing Narratives of Change. Identity and Legitimacy in Complex Innovative Infrastructure Organizations. Intervention Research, 2, 73-89.

[12] Koerten, H. and Veenswijk, M. (2009) Narrating National Geo Information Infrastructures: Balancing Infrastructure and Innovation. Journal of Service Science and Management, 2, 334. https://doi.org/10.4236/jssm.2009.24040

[13] Cunliffe, A.L., Luhman, J.T. and Boje, D.M. (2004) Narrative Temporality: Implications for Organizational Research. Organization Studies, 25, 261-286. https://doi.org/10.1177/0170840604040038

[14] Haack, P., Schoeneborn, D. and Wickert, C. (2012) Talking the Talk, Moral Entrapment, Creeping Commitment? Exploring Narrative Dynamics in Corporate Responsibility Standardization. Organization Studies, 33, 815-845. https://doi.org/10.1177/0170840612443630

[15] Langley, A.N.N., Smallman, C., Tsoukas, H. and Van de Ven, A.H. (2013) Process Studies of Change in Organization and Management: Unveiling Temporality, Activity, and Flow. Academy of Management Journal, 56, 1-13. https://doi.org/10.5465/amj.2013.4001

[16] Norbäck, M., Helin, J. and Raviola, E. (2014) Stabilizing Movements: How Television Professionals Use Other People's Voices to Cope with New Professional Practices during Times of Change. Journal of Change Management, 14, 434-452. https://doi.org/10.1080/14697017.2014.978532

[17] Boal, A. (2000) Theater of the Oppressed. Pluto Press, London.

[18] McClellan, J.G. (2014) Announcing Change: Discourse, Uncertainty, and Organizational Control. Journal of Change Management, 14, 192-209. https://doi.org/10.1080/14697017.2013.844195

[19] Beech, N., MacPhail, S.A. and Coupland, C. (2009) Anti-Dialogic Positioning in Change Stories: Bank Robbers, Savioursand Peons. Organization, 16, 335-352. https://doi.org/10.1177/1350508409102299

[20] Kaplan, S. and Orlikowski, W.J. (2013) Temporal Work in Strategy Making. Organization Science, 24, 965-995. https://doi.org/10.1287/orsc.1120.0792

[21] Schultz, M. and Hernes, T. (2013) A Temporal Perspective on Organizational Identity. Organization Science, 24, 1-21. https://doi.org/10.1287/orsc.1110.0731

[22] Ricoeur, P. (1984) Time and Narrative. Trans. McLaughlin K., Pellauer D., Vol. 1, University of Chicago Press, Chicago.

[23] Sartre, J.-P. (1968) Search for a Method. Trans. Hazel Estella Barnes, Vintage, New York.

[24] Gabriel, Y. (1993) Organizational Nostalgia: Reflections on “The Golden Age”. In: Fineman, S., Ed., Emotion in Organizations, Sage, London, 118-141.

[25] Ybema, S. (2004) Managerial Postalgia: Projecting a Golden Future. Journal of Ma- 
nagerial Psychology, 19, 825-841. https://doi.org/10.1108/02683940410568284

[26] Souto-Manning, M. (2014) Critical Narrative Analysis: The Interplay of Critical Discourse and Narrative Analyses. International Journal of Qualitative Studies in Education, 27, 159-180. https://doi.org/10.1080/09518398.2012.737046

[27] Foucault, M. (1977) Discipline \& Punish: The Birth of the Prison. Trans. Alan Sheridan, Penguin, London.

[28] Clegg, S.R. (1989) Frameworks of Power. Sage, London. https://doi.org/10.4135/9781446279267

[29] Hardy, C. and Maguire, S. (2010) Discourse, Field-Configuring Events, and Change in Organizations and Institutional Fields: Narratives of DDT and the Stockholm Convention. Academy of Management Journal, 53, 1365-1392. https://doi.org/10.5465/amj.2010.57318384

[30] Reay, T. and Hinings, C.R. (2009) Managing the Rivalry of Competing Institutional Logics. Organization Studies, 30, 629-652. https://doi.org/10.1177/0170840609104803

[31] Habermas, J. (1968) Technik und Wissenschaft als "Ideologie"? Man and World, 1, 483-523. https://doi.org/10.1007/BF01247043

[32] Phillips, N. and Hardy, C. (1997) Managing Multiple Identities: Discourse, Legitimacy and Resources in the UK Refugee System. Organization, 4, 159-185. https://doi.org/10.1177/135050849742002

[33] Carlsen, K. (2014) Constructing a Legitimate Argument-Narrative Techniques in the Ghana-EU VPA. Forest Policy and Economics, 48, 63-71. https://doi.org/10.1016/j.forpol.2014.09.017

[34] Vaara, E. and Tienari, J. (2002) Justification, Legitimization and Naturalization of Mergers and Acquisitions: A Critical Discourse Analysis of Media Texts. Organization, 9, 275-304. https://doi.org/10.1177/1350508402009002912

[35] Lieblich, A., Tuval-Mashiach, R. and Zilber, T. (1998) Narrative Research: Reading, Analysis, and Interpretation. Vol. 47, Sage, London. https://doi.org/10.4135/9781412985253

[36] Walgrave, S. and Varone, F. (2008) Punctuated Equilibrium and Agenda-Setting: Bringing Parties Back in: Policy Change after the Dutroux Crisis in Belgium. Governance, 21, 365-395. https://doi.org/10.1111/j.1468-0491.2008.00404.x

[37] Pauw (2014) [TV Program] 1: NOS.

[38] Van Rijn, J. (2013) Hervorming langdurige zorg: Naar een waardevolle toekomst. Drs. M.J. Van Rijn tothechairman of "de Tweede Kamer der Staten-Generaal”. https://www.rijksoverheid.nl/documenten/kamerstukken/2013/04/25/kamerbrief-he rvorming-langdurige-zorg-naar-een-waardevolle-toekomst

[39] Het Financiële Dagblad (2014) Gemeenten niet klaar voor decentralisatie zorg in 2015.

[40] NRC Handelsblad (2014) Verzekeraars: Voer zorgwet jaar later in.

[41] Heijne, S. (2014) Branche eensgezind: Het is te veel en te snel. https://www.volkskrant.nl/archief/branche-eensgezind-het-is-te-veel-en-te-snel a3 $\underline{636020 /}$

[42] Beverdam, G. (2014) Oppositie wil plannen voor langdurige zorg uitstellen banenplan voor zorg Nederlands Dagblad (Amersfoort).

[43] Het Parool (2014) Van Rijn wil zijn zorgwet niet uitstellen.

[44] Landeweer, M. (2014) Radeloze Joop (81): Soms loopt urine langs haar enkels. Algemeen Dagblad. 